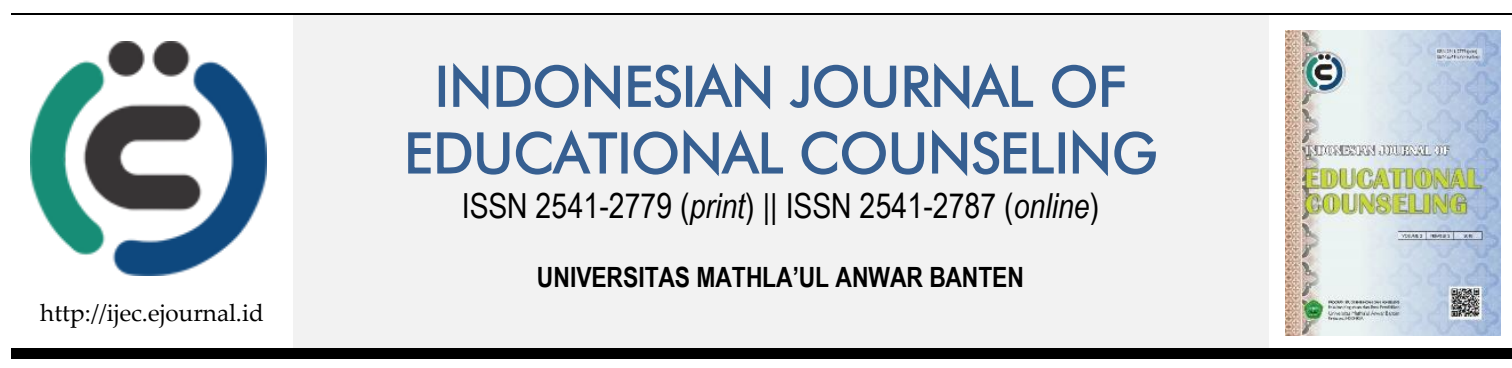

Theoretical/Conceptual Article

\title{
Analisis Teori Ekspresi Cinta Remaja Sebagai Pencegahan Perilaku Seksual Berisiko dengan Menggunakan Strategi Penekanan Ekspresif
}

\author{
Agrery Ayu Nadiarenita ${ }^{1}$, Nur Hidayah ${ }^{2}$ \\ 1, 2 Universitas Negeri Malang
}

\begin{tabular}{l} 
ARTICLE INFO \\
\hline Article History: \\
Received 12.12.2017 \\
Received in revised \\
form 24.05.2018 \\
Accepted 27.06.2018 \\
Available online \\
22.07.2018
\end{tabular}

\begin{abstract}
Love is a form of positive emotion expressed differently by each individual. As a positive emotion, love should be interpreted as an element of emotion in which there is mutual respect, trust and respect for each other in order to maintain the relationship of sexual attraction that cause feelings of pleasure. Expression of love is now interpreted as a negative emotion in which the urge of passions that play a big role in a relationship. Sexual impacts will affect teenagers when the relationship is sustained, including increased rates of pregnancy out of wedlock, dropping out of school, and increased HIV/AIDS transmission. Based on a survey conducted by several agencies stating that Indonesia is an emergency against teenage sexual behavior. Therefore, this study was conducted with the aim to find solutions to adolescent problems in order to prevent excessive love expression. Expressive suppression strategy as a response modulation strategy is expected to be a solution for teenagers. Use of this strategy by applying the stages in emotional regulation. The effectiveness of this technique to prevent excessive love expression needs to be proven in further research so that it can be used to assist school counselors in dealing with students.
\end{abstract}

Keywords: Adolescent Love, Expressive Suppression Strategy, Sexual Behavior.

This is an open access article distributed under the terms of the Creative Commons Attribution 4.0 International License, which permits unrestricted use, distribution, and reproduction in any medium, provided the original work is properly cited. ○ 2018 Agrery Ayu Nadiarenita, Nur Hidayah.

\section{PENDAHULUAN}

Perbincangan tentang seksual sudah tidak dianggap tabu lagi, bahkan menjadi topik yang menarik. Dalam kehidupan masyarakat yang penuh dengan nilai-nilai kehidupan Timur yang didominasi oleh ajaran-ajaran agama dan budaya diatur tingkah laku seksual atau nilai-nilai yang berhubungan dengan seksual secara normatif. Konsep seksual normatif adalah nilai-nilai yang telah terinstitusionalisasi dalam kehidupan masyarakat dan konsep ini yang dipandang sebagai etnik masyarakat dalam memperlakukan seksual

${ }^{1}$ Corresponding author’s address: Universitas Negeri Malang. Email: nadiaagrery@ gmail.com. 
mereka (Bangin, 2003). Bahkan hubungan seks sebelum menikah dianggap "benar" apabila orang-orang yang terlibat saling mencintai ataupun saling terikat. Mereka sering merasionalisasikan tingkah laku seksual mereka dengan mengatakan pada diri mereka sendiri bahwa mereka terhanyut cinta. Sejumlah peneliti menemukan bahwa remaja perempuan, lebih daripada remaja laki-laki, mengatakan bahwa alasan utama mereka aktif secara seksual adalah karena jatuh cinta (Santrock, 2012).

Analisis mengenai teori ekspresi cinta remaja ini merupakan upaya untuk mengetahui kecenderungan emosi siswa yang memasuki usia remaja dengan diwujudkan dalam perilaku yang positif maupun negatif. Ekspresi cinta diasumsikan memiliki potensi hasrat seksual yang lebih tinggi yang dapat mengarahkan individu untuk berperilaku ke arah negatif dalam hal ini mengarah pada perilaku seksual pranikah. Ketika seseorang jatuh cinta, maka dia akan dapat merasakan perasaan bahagia, kagum, rasa memiliki dan selalu ingin berbagi dengan orang yang dicintai dan perasaan lainnya. Demikian juga ketika seseorang mengalami putus cinta atau dikecewakan oleh orang yang dicintai, maka perasaan cinta tadi akan dapat berubah menjadi perasaan marah, benci, kecewa dan lain sebagainya. Perasaan jatuh cinta yang berlebihan akan mendorong individu untuk melakukan segala hal untuk memenuhi hasrat seksualnya, termasuk melanggar normanorma yang ada di masyarakat.

Data Survei Kesehatan Reproduksi Remaja Indonesia (2007), didapatkan bahwa remaja (15-19 th) sebagian telah melakukan seks bebas (BPS \& Macro International, 2007; BKKBN, 2008; Imron, 2012). Hasil survei Perkumpulan Keluarga Berencana Indonesia (PKBI) Jawa Tengah yang dimuat pada situs media online jateng.tribunnews.com pada hari Rabu, 6 November 2013 menunjukkan sekitar 29 persen siswa SMA dan SMK setuju untuk melakukan hubungan pranikah. Survei yang diadakan pada tahun 2012 tersebut melibatkan 1.355 responden siswa SMA dan SMK di Semarang dimana terungkap ada 1.624 remaja atau 75.2 persen dari 2.159 responden memiliki perilaku seks berisiko. Perilaku seks berisiko disini diartikan sebagai gaya berpacaran yang disertai ciuman, petting (menyentuk dan memijit daerah rangsangan seksual), bahkan sudah melakukan hubungan seks di luar nikah. Selain itu, menurut survei Komnas Perlindungan Anak yang diunggah solopos.com tanggal 23 Juni 2013 yang bekerja sama dengan Lembaga Perlindungan Anak (LPA) di 12 kota besar di Indonesia tahun 2011 hasilnya dari 4.726 anak yang diteliti, 93.7 persen diantaranya pernah melakukan ciuman, genital stimulan, petting sampai oral seks, sementara 62,7 persen remaja SMP yang diteliti mengaku sudah tidak perawan. Hasil survei juga mengatakan 21.2 persen remaja SMA melakukan abori dan 97 persen remaja SMP/SMA melihat film porno. Dimana media memegang peranan sangat penting dalam menyebarluaskan informasi, disamping membaca media cetak, semakin banyak remaja terpapar oleh informasi melalui televisi dan internet (Survei Kesehatan Reproduksi Remaja Indonesia, 2007).

Hasil survei tersebut cukup memprihatinkan dimana makna cinta yang sesungguhnya tidak diekspresikan dalam perilaku yang tepat. Dari segi perkembangan usia, remaja didefinisikan sebagai masa peralihan dari masa anak-anak menuju masa dewasa. WHO (dalam Sarwono, 2005) mengatakan remaja adalah suatu masa ketika individu berkembangan dari saat pertama kali ia menunjukkan tanda-tanda sekundernya sampai saat ia mencapai kematangan seksual. Batasan usia remaja menurut WHO (badan PBB untuk kesehatan dunia) adalah 10 sampai 20 tahun. Data hasil survei oleh Perkumpulan Keluarga Berencana Indonesia (PKBI) Jawa Tengah tersebut sebenarnya terjadi ketimpangan apabila dikatikan dengan perkembangan seksual remaja yang 
didasarkan pada usia. Pada usia tersebut individu masih dalam tahap menunjukkan tanda-tanda seksual sekundernya saja dan belum sampai pada kematangan seksual.

Cinta yang diwujudkan dalam suatu hubungan seks di luar nikah memang menjadi salah satu jalan yang dipilih oleh remaja saat ini sebagai bentuk pemaknaan cinta yang sesungguhnya. Berbagai dampak dari pilihan remaja dalam mengekspresikan cinta diantaranya data yang diperoleh dari Humas Pengadilan Agama Kabupaten Ponorogo pada tahun 2016 yang dimuat di sindonews.com tanggal 9 Agustus 2016 menyatakan bahwa kasus pelajar hamil di Ponorogo mengalami peningkatan dibanding tahun sebelumnya tahun 2015, tercatat ada 47 kasus pelajar SMA dan SMP yang hamil serta putus sekolah. Uraian data menggambarkan bahwa kelompok remaja sangat rentan melakukan perilaku seks bebas yang memungkinkan terjadi penularan Penyakit Menular Seksual (PMS) atau HIV/AIDS. Hal ini dikuatkan dari data Kementerian Kesehatan bahwa kasus AIDS terbanyak pada kelompok usia 20-29 tahun akibat penyebaran HIV yang terjadi pada saat masih remaja (BKKBN, 2013).

Semakin banyak data yang menunjukkan bahwa ekspresi cinta yang berlebihan akan berdampak pada masa depan yang suram. Putus sekolah seakan-akan menjadi pilihan terakhir untuk mengatasi permasalahan ini. Pengekspresian cinta yang sudah mengarah pada perilaku seksual pranikah harus dicegah dalam rangka menyelamatkan masa depan remaja yang seharusnya menjadi orientasi hidupnya saat ini. Pengelolaan emosi cinta salah satunya dilakukan dengan menggunakan strategi expressive suppression. Strategi ini diharapkan dapat menjadi upaya prevensi perilaku seksual pranikah dengan menekan ekspresi emosi cinta negatif dan memunculkan emosi cinta secara wajar sebagai bentuk perkembangan emosional remaja.

Permasalahan mengenai perilaku seksual pranikah sebagai bentuk pengekspresian emosi cinta remaja saat ini, dan disisi lain diperlukan adanya upaya prevensi sehingga kedepannya tingkat perilaku seksual remaja akan mengalami penurunan. Strategi expressive suppression yang diterapkan dalam tahapan regulasi emosi akan dijabarkan sebagai solusi untuk mencegah permasalahan di lapangan berkaitan dengan perasaan jatuh cinta. Beberapa konsep akan diuraikan dalam rangka mendukung upaya prevensi perilaku seksual pranikah, diantaranya mengenai: (1) konsep ekspresi cinta remaja; (2) perilaku seksual pranikah sebagai dampak ekspresi cinta; (3) strategi expressive suppression dalam regulasi emosi.

\section{KAJIAN LITERATUR}

\section{Konsep Ekspresi Cinta Remaja}

Shaver, Morgan, dan Wu (1996) mengartikan cinta sebagai bagian terpenting dari pemandangan emosional. Lebih jauh dari pada itu, menurut Freud (Bachtiar, 2004) cinta sudah muncul ketika anak berada pada fase phalik yang ditandai dengan Oedipus complex. Sejalan dengan berkembangnya fisik dan emosional pada remaja, cinta pada masa anakanak mengalami perubahan orientasi dari yang sebelumnya berorientasi kepada keluarga kini remaja sudah menaruh minat pada hubungan lawan jenis atau disebut dengan pacaran.

Pacaran adalah masa dimana dua orang sepakat untuk menjalin hubungan lebih dalam dan saling berbagi baik berbagi pikiran maupun perasaan. Pacaran terjadi karena adanya kerinduan untuk menjalin interaksi dengan orang lain, seperti pendapat seorang tokoh humanis, Abraham Maslow (1943) menyebut bahwa orang akan mendambakan 
hubungan penuh kasih sayang dan cinta dengan orang lain, dan secara naluriah akan berusaha untuk mencapai tujuan ini. Dalam teorinya tentang segitiga cinta, Sternberg (Strongman, 2003) mengemukakan tiga komponen yang terdapat dalam sebuah hubungan cinta. Tiga komponen tersebut adalah (1) Keintiman (Intimacy), yaitu elemen emosi yang didalamnya terdapat kehangatan, kepercayaan (trust), saling menghormati dan menghargai satu sama lain, saling terbuka, dan keinginan untuk membina hubungan; (2) Gairah (Passion), yaitu elemen motivasional yang didasari oleh ketertarikan terhadap daya tarik fisik dan daya tarik seksual sehingga menimbulkan perasaan senang, berbunga-bunga, dan terpesona; dan (3) Komitmen (Commitment), yaitu elemen kognitif (logika dan perasaan) dalam bentuk tindakan seperti menerima pasangan tanpa syarat, turut menjaga dan melindungi suatu hubungan dari masa kritis.

Ketiga dimensi cinta tersebut berkombinasi menghasilkan delapan tipe hubungan cinta yang berbeda, yaitu (1) Tidak ada cinta (non-love) adalah hubungan yang tidak didasari pada ketiga komponen segitiga cinta, contohnya hubungan guru dan siswa; (2) Rasa suka (liking) adalah ciinta yang terdiri dari keintiman semata dimana hubungan secara esensial dimaknai sebagai hubungan persahabatan; (3) Cinta tergila-gila (infatuation) adalah cinta yang hanya dibangun oleh komponen nafsu dan bersifat obsesif; (4) Cinta kosong (empty love) adalah cinta yang dilandasi unsure komitmen saja tanpa adanya keintiman dan nafsu dimana terjadi dalam kisah cinta yang bertepuk sebelah tangan; (4) Cinta romantis (romantic love) adala hubungan cinta yang didasarkan pada komponen nafsu dan keintiman sehingga diwarnai dengan nafsu yang kuat dan keinginan untuk menjalin hubungan yang lebih dekat; (5) Cinta karib (companionate love) adalah hubungan yang dibangun atas dasar keintiman dan komitmen; (6) Cinta konyol (Fatous love) adalah cinta yang terbangun oleh komponen komitmen dan nafsu di dalamnya, namun hanya terdapat sedikit komponen keintiman; (7) Cinta sempurna (consummate love) yaitu sebuah bentuk cinta ideal, yakni terlibatnya ketiga unsur pembentuk cinta.

Hubungan cinta yang terjadi pada remaja dapat dikategorikan sebagai cinta romantis, menunjukkan serangkaian hubungan yang hanya ada dalam waktu yang relatif singkat yang didasarkan pada gagasan dua orang yang terpisah dan otonom yang bebas memilih (Strongman, 2003). Seringkali cinta romantis yang diinginkan oleh remaja tidak sesuai dapat membuat seseorang berpikir imajinatif yang mana akan individu akan membuat kisahnya sendiri. Kecenderungan remaja untuk membuat kisah dalam kehidupan cintanya berpengaruh terhadap bentuk pengekspresian cinta itu sendiri, karena pada dasarnya cinta tidak bisa dipisahkan dari ekspresi, ekspresi penting karena hanya dengan ekspresi esensi dari cinta yang bersifat abstrak dapat dirasakan dana dapat dinikmati.

Pengekspresian cinta dalam bentuk perilaku dilakukan oleh remaja SMA sebagai bentuk peningkatan emosional yang terjadi secara cepat pada masa remaja awal. Dari segi kondisi sosial, peningkatan emosi ini merupakan tanda bahwa remaja berada dalam kondisi baru yang berbeda dari masa sebelumnya. Bentuk pengekspresian emosi cinta ini berupa perilaku positif ataupun perilaku negatif. Perilaku sebagai bentuk ekspresi cinta ini berkaitan dengan rasa ingin tahu terhadap masalah seksual sangat penting dalam pembentukan hubungan yang lebih matang dengan lawan jenis. Matangnya fungsi-fungsi seksual maka timbul pula dorongan-dorongan dan keinginan-keinginan untuk pemuasan seksual. Sebagian besar dari remaja biasanya sudah mengembangkan perilaku seksualnya dengan lawan jenis dalam bentuk pacaran atau percintaan. Bila ada kesempatan para remaja melakukan sentuhan fisik, mengadakan pertemuan untuk bercumbu bahkan 
kadang-kadang remaja tersebut mencari kesempatan untuk melakukan hubungan seksual.

Hubungan seksual yang dilakukan tanpa adanya ikatan perkawinan dapat dikatakan sebagai ekspresi cinta romantis yang berlebihan dari diri remaja. Hubungan seksual juga yang dibentuk oleh individu didorong oleh hasrat seksual, baik dengan lawan jenisnya maupun dengan sesama jenis (Sarwono, 2015). Hasrat seksual yang dipengaruhi oleh emosi cinta tersebut harus diatur dalam rangka mengurangi hubungan seksual pranikah sebagai pengaplikasian imajinasi untuk membentuk cinta yang romantis.

Ekspresi cinta remaja yang mengarah pada hubungan seksual masuk pada tahap I dimana remaja dalam proses jatuh cinta (Kokab \& Ajmal, 2012). Pada tahap I ini seseorang terlibat dalam cinta yang buta, yang mana dapat dilihat dengan mengabaikan kualitas buruk pasangan meskipun mengetahui bahwa mereka hadir dan juga mengganggu. Ketika individu berada pada tahap ini mereka akan kehilangan logika berpikir sehingga melakukan segala cara untuk mengekspresikan cinta buta. Kokab \& Ajmal (2012) juga menyebutkan bahwa ketika individu sudah memasuki tahap II maka terdapat berbagai faktor yang menyebabkan kebahagian diantaranya yaitu komitmen, romantisme, pengertian, kejujuran, fantasi, harapan, persahabatan yang ideal, dan keterbukaan. Pada tahap dua ini individu semakin dapat memaknai arti cinta yang sesungguhnya dimana prosesnya akan mengarah pada terciptanya kebahagiaan. Tahap terakhir dari teori persepsi cinta adalah tahap III dimana cinta terus berlanjut dan akhirnya mengarah pada ekspektasi pernikahan (Kokab \& Ajmal, 2012). Pada tahap ini individu tidak mengekspresikan cinta secara berlebihan, tetapi lebih berfokus pada persiapan untuk menghadapi kehidupan selanjutnya yaitu pernikahan.

Berdasarkan kajian mengenai ekspresi cinta maka pemaknaan masing-masing orang berbeda satu sama lain. Ekspresi cinta bisa dimaknai sebagai emosi cinta positif maupun negatif. Pengekspresian cinta dalam hal ini termasuk dalam tahapan jatuh cinta dalam teori persepsi cinta dimana seseorang akan menampakkan emosi dalam bentuk perilaku seksual. Kemunculan perilaku seksual tersebut sebagai dampak dari dorongan nafsu yang berlebihan dan keintiman yang terjadi dalam proses jatuh cinta.

\section{Perilaku Seksual Pranikah Sebagai Dampak Ekspresi Cinta}

Pengertian pranikah menurut Kamus Besar Bahasa Indonesia (2001), kata pra berarti sebelum, sedangkan nikah berarti perjanjian antara laki-laki dan perempuan untuk bersuami istri dengan resmi. Secara umum pranikah didefinisikan sebagai hal yang terjadi sebelum adanya perjanjian antara laki-laki dan perempuan untuk bersuami istri dengan resmi. Perilaku seksual pranikah adalah segala tingkah laku yang didorong oleh hasrat seksual dengan lawan jenisnya, melalui perbuatan yang tercermin dalam tahap-tahap perilaku seksual dari tahap yang paling ringan hingga tahap yang paling berat yang dilakukan sebelum pernikahan yang resmi menurut hukum maupun agama.

Menurut Sakti dan Kusuma (2006) hubungan seksual adalah bertemunya dua alat kelamin yang berlainan jenis. Dalam hubungan seksual terdapat aktivitas seksual seperti oral seks atau menggesekkan alat kelamin ke bagian-bagian tertentu organ tubuh pasangannya. Pengertian hubungan seksual dikemukakan juga oleh Sarwono (2015) perilaku seksual adalah segala tingkah laku yang didorong oleh hasrat seksual, baik dengan lawan jenisnya maupun dengan sesama jenis. Bentuk-bentuk tingkah laku ini dapat beraneka ragam, mulai dari perasaan tertarik hingga tingkah laku berkencan, 
bercumbu, dan bersenggama. Dari beberapa definisi di atas dapat disimpulkan bahwa hubungan seksual pranikah adalah hubungan perilaku seksual yang didorong oleh hasrat seksual baik dengan lawan jenis maupun sesama jenisnya sebelum adanya ikatan atau perjanjian antara laki-laki dan perempuan untuk bersuami istri dengan resmi.

Edelman dan Mandle (2001) menyebutkan bahwa perubahan kondisi fisik pada remaja adalah ketika remaja memasuki masa pubertas, menstruasi pertama pada remaja putrid dan perubahan suara pada remaja putra (Perry \& Potter, 2009). Pada remaja yang sudah puber, produksi hormone menjadi aktif. Hormon aktif tersebut adalah folliclestimulating hormone (FSH) dan luteinizing hormone (LH). Perbedaan perubahan hormonal pada tiap remaja berdampak pada perbedaan pertumbuhan yang terjadi pada remaja. Remaja yang tumbuh lebih lambat dibandingkan dengan remaja lain cenderung merasa malu dan minder, sebaliknya remaja yang tumbuh cepat, berbadan besar akan merasa kuat dan hebat sehingga terkadang remaja tersebut merasa menjadi jagoan. Perbedaan pertumbuhan ini dapat menimbulkan masalah pada remaja.

Perilaku seksual pranikah ini mempunyai risiko yang besar dimana antara laki-laki dan perempuan yang melakukan akan menanggung dampak dari hubungan tidak wajar yang dilakukan. Kasim (2014) menyebutkan ada tiga dampak apabila remaja melakukan hubungan seksual pranikah yaitu (1) kehamilan yang tidak diinginkan (unwanted pregnancy), (2) tertular penyakit menular seksual atau HIV/AIDS, dan (3) konsekuensi psikologis. Dampak yang pertama berkaitan dengan kehamilan yang tidak diinginkan akan membawa remaja pada dua pilihan yaitu melanjutkan kehamilan atau menggugurkannya.

Kedua pilihan di atas mempunyai konsekuensi tersendiri bagi remaja dimana ketika pilihan untuk melanjutkan kehamilan harus dibayar dengan keputusan untuk berhenti sekolah dan sanksi sosial dari masyarakat. Sanksi sosial yang mana merupakan konsekuensi psikologis akan membuat remaja merasa malu, cemas dan bersalah ketika kehamilannya diketahui oleh orang lain. Sedangkan pilihan pengguguran kandungan akan mengancam nyawa karena terjadinya perdarahan pada trisemester pertama dan ketiga, anemi dan persalinan kasip merupakan komplikasi yang sering terjadi pada kehamilan anak muda (Wibowo, 1994). Selain itu, anak muda seringkali melakukan hubungan seks yang tidak aman dengan kebiasaan berganti-ganti pasangan dan melakukan anal seks menyebabkan anak muda semakin rentan tertular penyakit menular seksual seperti sifilis, gonore, herpes, klamidia, dan AIDS.

Berdasarkan penjelasan mengenai perilaku seksual pranikah maka disebutkan bahwa segala tingkah laku yang didorong oleh hasrat seksual dengan lawan jenisnya, melalui perbuatan dari tahap yang paling ringan hingga tahap yang paling berat yang dilakukan sebelum pernikahan. Kondisi yang membuat remaja menjadi berisiko dari aspek biologis dan usia adalah perubahan yang sangat cepat pada remaja (Stanhope \& Lancester, 2004). Hal ini menyebabkan remaja menjadi seseorang yang mengekspresikan cinta dalam bentuk perilaku seksual pranikah.

\section{Strategi Expressive Suppression dalam Regulası Emosı}

Dalam psikologi, expressive suppression atau penekanan ekspresif adalah salah satu strategi regulasi emosi. Gross (2014) mendefinisikan Expressive Suppression sebagai strategi modulasi respon yang melibatkan individu untuk mengurangi perilaku emosi yang ekspresif ketika individu sudah dalam keadaan emosional. Penekanan ekspresif dilakukan untuk menyembunyikan, menghambat atau mengurangi perilaku ekspresif 
yang terus-menerus (Gross \& Levenson, 1993; Gross \& John, 2003; Cutuli, 2014). Ekspresi emosi sangat penting untuk komunikasi informasi sosial seperti keadaan emosional dan perilaku. Setiap individu cenderung memiliki tingkat ekspresi emosinal bervariasi.

Meta analisis menunjukkan bahwa penekanan emosi yang lebih besar dikaitkan secara signifikan dengan kesejahteraan sosial yang lebih buruk, termasuk pembentukan kesan yang negatif, dukungan sosial yang rendah, kepuasan dan kualitas sosial yang rendah, dan kualitas hubungan romantis yang buruk (Chervonsky \& Hunt, 2017). Ekspresi emosi positif akan terkait dengan hasil sosial yang lebih baik, sementara ekspresi kemarahan dikaitkan dengan kesejahteraan sosial yang lebih buruk. Dengan demikian, penekanan ekspresif sebagai strategi modulasi respon dapat dimainkan dalam pengembangan disfungsi sosial dan masalah interpersonal.

Penekanan ekspresif yang berkaitan dengan masalah interpersonal melibatkan mengurangi ekspresi wajah dan mengendalikan perasaan emosi positif dan negatif. Jenis strategi pengaturan emosi ini dapat memiliki efek emosional dan psikologis yang negatif pada individu. Penekanan emosional mengurangi perilaku ekspresif secara signifikan. Seperti banyak peneliti telah menyimpulkan, meskipun penekanan emosional mengurangi emosi ekspresif luar, hal itu tidak mengurangi perasaan negatif dan emosi kita (Niedenthal dkk, 2006). Penekanan ekspresif sebagai salah satu strategi regulasi emosi dapat diterapkan dengan menggunakan tahapan regulasi emosi.

Penerapan strategi expressive suppression tersebut dapat digunakan dengan dimasukkan pada tahapan regulasi emosi. Gross (2014) mengemukakan bahwa ada lima tahapan atau proses regulasi emosi pada individu diantaranya: (1) Pemilihan Situasi (Situation Selection); (2) Modifikasi Situasi (Situation Modification); (3) Penyebaran Perhatian (Attention Deployment); (4) Perubahan Kognitif (Cognitive Change); dan (5) Penyesuaian Respon (Respon Modulation).

Situation selection yaitu suatu tindakan untuk memungkinkan kita berada dalam situasi yang kita harapkan dan menimbulkan emosi yang kita inginkan. Dengan kata lain strategi ini dapat berupa mendekati atau menghindar dari seseorang, tempat, atau objek berdasarkan dampak emosi yang muncul. Setelah proses pemilihan situasi maka individu akan melakukan usaha untuk memodifikasi satu keadaan secara langsung untuk mendatangkan suatu keadaan baru. Modifikasi situasi yang dimaksud di sini dapat dilakukan dengan memodifikasi lingkungan fisik eksternal maupun internal. Gross (2007) menganggap bahwa upaya memodifikasi "internal" lingkungan yaitu pada bagian perubahan kognitif. Misalkan jika salah satu pasangan tampak sedih, maka dapat menghentikan interaksi marah kemudian mengungkapkan dengan keprihatinan, meminta maaf, atau memberikankan dukungan.

Attentional deployment dapat dianggap sebagai versi intenal dari seleksi situasi. Dua strategi atensional yang utama adalah distraksi dan konsentrasi. Distraksi memfokuskan perhatian pada aspek-aspek yang berbeda dari situasi yang dihadapi, atau memindahkan perhatian dari situasi itu ke situasi lain, misalnya ketika seorang bayi mengalihkan pandangannya dari stimulus yang membangkitkan emosi untuk mengurangi stimulasi. Attentional deployment bisa memiliki banyak bentuk, termasuk pengalihan perhatian secara fisik (misalnya menutup mata atau telinga), pengubahan arah perhatian secara internal (misalnya melalui distraksi atau konsentrasi), dan merespon pengalihan.

Perubahan perhatian akan mengarah perubahan kognitif yang ditandai dengan perubahan penilaian yang dibuat dan termasuk di sini adalah pertahanan psikologis dan 
pembuatan pembandingan sosial dengan yang ada di bawahnya (keadaannya lebih buruk daripada saya). Pada umumnya, hal ini merupakan transformasi kognisi untuk mengubah pengaruh kuat emosi dari situasi. Perubahan kognitif mengacu pada mengubah cara kita menilai situasi di mana kita terlibat di dalamnya untuk mengubah signifikansi emosionalnya, dengan mengubah bagaimana kita memikirkan tentang situasinya atau tentang kapasitas kita untuk menangani tuntutan-tuntutannya. Langkah yang terakhir yaitu modulasi respon yang mengacu pada mempengaruhi respon fisiologis, pengalaman, atau perilaku selangsung mungkin. Olahraga dan relaksasi juga dapat digunakan untuk mengurangi aspek-aspek fisiologis dan pengalaman emosi negatif, dan, alkohol, rokok, obat, dan bahkan makanan, juga dapat dipakai untuk memodifikasi pengalaman emosi.

\section{DISKUSI}

Cinta yang dialami oleh remaja merupakan suatu perasaan yang diidentikkan sebagai rasa bahagia, senang dan berbunga-bunga. Cinta juga dimaknai sebagai sesuatu yang harus diekspresikan dalam bentuk perilaku yang memunculkan fantasi ketika seorang remaja sedang berada jauh dari pasangannya. Perasaan bahagia harus muncul sebagai dampak dari proses jatuh cinta. Pengekspresian rasa bahagia ini tidak hanya dalam bentuk perilaku positif tetapi seringkali mengarah pada hal-hal yang sifatnya negatif. Ada beberapa hal yang menyebabkan remaja melakukan perilaku seksual pranikah. Stanhope dan Lancaster, menyebutkan bahwa karakteristik berisiko yaitu ke arah hubungan seksual (at risk) mencakup risiko biologik dan usia; sosial; ekonomi; lingkungan; gaya hidup; dan kejadian dalam hidup. Kondisi yang membuat remaja menjadi kelompok berisiko dari aspek biologis dan usia adalah perubahan yang sangat cepat pada remaja (Stanhope \& Lancaster, 2004).

Selain itu, Kasmiran (Lisnawati \& Lestari, 2015) menyebutkan bahwa faktor-faktor yang mempengaruhi terjadinya perilaku seksual pada remaja selain perubahan biologis yang terjadi pada masa pubertas dan pengaktifan hormonal maka kurangnya peran orang tua melalui komunikasi antara orang tua dan remaja seputar masalah seksual dapat memperkuat munculnya penyimpangan perilaku seksual, serta pengetahuan remaja yang rendah cenderung lebih sering memunculkan aktivitas seksual dibandingkan dengan remaja yang berpengetahuan baik, kemudian pengaruh teman sebaya sehingga memunculkan penyimpangan perilaku seksual. Pengekspresian cinta remaja dalam hal ini juga seharusnya mendapatkan perhatian oleh orang tua dimana saat ini dengan semakin berkembangannya teknologi dan semakin mudahnya informasi diakses melalui media sosial.

Ekspresi cinta dapat dilakukan dengan menggunakan verbal maupun non verbal. Penggunaan media sosial juga memberikan pengaruh yang sangat besar dalam pengekspresian cinta secara non verbal. Menurut peneliti dari North Caroline (Iswarati \& Prihyugiarto, 2008) menyebutkan bahwa secara umum remaja yang paling banyak mendapat dorongan seksual dari media cenderung melakukan seks pada usia 14 hingga 1 tahun 2,2 kali lebih tinggi disbanding remaja lain yang lebih sedikit melihat eksploitasi seks dari media. Media yang dimaksudkan adalah media sosial dimana terdapat facebook, twitter, instagram, whatsapp, dan lain-lain.

Sedangkan pengekspresian cinta melalui verbal juga semakin banyak terjadi. Remaja seringkali terpengaruh teman untuk mengekspresikan cintanya sehingga tanpa sadar 
mereka melakukan hubungan seksual pranikah. Wulandari (2016) menjelaskan bahwa berdasarkan penelitian yang telah dilakukan maka 12,1\% remaja dari 380 orang sampel melakukan perilaku seksual pranikah berisiko terhadap Kehamilan Tidak Diinginkan (KTD). Hal tersebut patut menjadi perhatian bagi konselor untuk mencari solusi dalam rangka mencegah perilaku seksual pranikah. Penggunaan strategi emosi dapat digunakan untuk mencegah luapan emosi positif maupun negatif yang berlebihan.

Salah satu strategi pengaturan emosi yaitu dengan melakukan expressive suppression. Penekanan ekspresif adalah strategi yang berfokus pada respon yang campur tangan begitu emosi sudah berjalan dan setelah respons perilaku telah sepenuhnya dihasilkan (Cutuli, 2014). Dengan demikian mungkin diharapkan memerlukan usaha berulang untuk mengelola respons emosional saat mereka terus muncul, menantang sumber daya individu. Penggunaan strategi expressive suppression digunakan dengan pertimbangan bahwa strategi ini sudah pernah digunakan dalam rangka mengurangi perilaku merokok. Rani dan Subekti (2013) menyatakan bahwa terdapat hubungan yang signifikan antara gaya kelekatan menghindar dengan strategi regulasi emosi expressive suppression pada remaja perokok. Dengan demikian, dapat disimpulkan bahwa hipotesis dari kajian ini adalah strategi expressive suppression dapat digunakan untuk mencegah perilaku seksual pranikah sebagai dampak pengekspresian emosi cinta remaja.

\section{SIMPULAN}

Cinta sebagai salah satu bentuk emosi positif seringkali diekspresikan dalam perilaku yang tidak wajar atau negatif. Pengekspresian cinta dirasionalisasikan menjadi sebuah bentuk perilaku hubungan seksual pranikah oleh remaja SMA sebagai bentuk peningkatan emosional yang terjadi secara cepat pada masa remaja awal. Dari segi kondisi sosial, peningkatan emosi ini merupakan tanda bahwa remaja berada dalam kondisi baru yang berbeda dari masa sebelumnya. Pemaknaan cinta yang berbeda ini dan mengarah pada perilaku seksual pranikah akan berdampak pada hilangnya masa depan remaja. Pencegahan dapat dilakukan dengan menggunakan strategi expressive suppression sebagai salah satu strategi dalam meregulasi emosi. Penerapan strategi expressive suppression ini dilakukan mengikuti tahapan regulasi emosi yaitu (1) Pemilihan Situasi (Situation Selection); (2) Modifikasi Situasi (Situation Modification); (3) Penyebaran Perhatian (Attention Deployment); (4) Perubahan Kognitif (Cognitive Change); dan (5) Penyesuaian Respon (Respon Modulation).

Penerapan strategi expressive suppression ini harus dilakukan penelitian kuantitatif terlebih dahulu untuk mengetahui tingkat keefektivannya sehingga dapat digunakan sebagai strategi untuk mengelola ekspresi cinta remaja. Pengujian dapat dilakukan dengan membandingkan strategi expressive suppression dan strategi cognitive reapprasial sebagai strategi regulasi emosi yang diungkapkan oleh Gross. Namun demikian, strategi ini juga bisa dibandingkan dengan strategi bimbingan kelompok seperti bibliokonseling sehingga ketika strategi ini diterapkan sudah teruji efektivitasnya. Selain itu, bagi peneliti selanjutnya juga perlu dikembangkan panduan pelatihan bagi konselor dalam menggunakan strategi expressive suppression untuk membantu siswa mengelola ekspresi cintanya sebagai prevensi perilaku seksual pranikah. 


\section{REFERENSI}

Bangin, B. (2003). Pornomedia konstruksi sosial teknologi telematika dan perayaan seksual di media massa. Jakarta: Prenada Media.

BKKBN. (2013). Hanya 20 persen Remaja Paham HIV/AIDS. Retrieved November 20, 2017, from http://www.bkkbn.go.id/ViewBerita.aspx?BeritaID=701

BPS, \& Macro International. (2007). Survei kesehatan reproduksi remaja Indonesia 2007. Calverton, Maryland, USA: BPS \& Macro International.

Chervonsky, E., \& Hunt, C. (2017). Suppression and expression of emotion in social and interpersonal outcomes: A meta-analysis. Emotion, 17(4), 669-683. doi: $10.1037 / \mathrm{emo} 0000270$

Cutuli, D. (2014). Cognitive reappraisal and expressive suppression strategies role in the emotion regulation: an overview on their modulatory effects and neural correlates. Frontiers in Systems Neuroscience, 8(175), 1-6. doi: 10.3389/fnsys.2014.00175

Gross, J. J. (2007). Handbook of emotion regulation. New York: The Guildford Press.

Gross, J. J. (2014). Emotion regulation. New York: The Guilford Press

Gross, J. J., \& John, O. P. (2003). Individual differences in two emotion regulation processes: implications for affect, relationships, and well-being. Journal of Personality and Social Psychology, 85(2), 348-362. doi: 10.1037/0022-3514.85.2.348

Gross, J. J., \& Levenson, R. W. (1993). Emotional suppression: physiology, self-report, and expressive behavior. Journal of Personality and Social Psychology, 64(6), 970-986.

Hasan, I. (2002). Pokok-pokok materi metodologi penelitian dan aplikasi. Jakarta: Ghalia Indonesia.

Iswarati, \& Prihyugiarto, T. Y. (2008). Faktor-faktor yang mempengaruhi sikap terhadap perilaku seksual pra nikah pada remaja di Indonesia. Jakarta: Puslitbang KB dan Kesehatan Reproduksi BKKBN. Jakarta.

Kasim. F. (2014). Dampak perilaku seks berisiko terhadap kesehatan reproduksi dan upaya penanganannya (studi tentang perilaku seks berisiko pada usia muda di Aceh). Jurnal Studi Pemuda, 3(1), 39-48.

Kokab, S., \& Ajmal, M. A. (2012). Perception of love in young adults. Pakistan Journal of Social and Clinical Psychology, 9(2), 43-48. 
Komnas PA. (2013). Awas! Indonesia darurat nasional kekerasan seks pada anak. Retrivied June 23, 2013, from http://www.solopos.com/2013/06/23/komnas-pa-awas-indonesiadarurat-nasional-kekerasan-seks-pada-anak-418951.

Lisnawati, \& Lestari, N. S. (2015). Faktor-faktor yang berhubungan dengan perilaku seksual remaja di Cirebon. Care: Jurnal Ilmiah Ilmu Kesehatan, 3(1), 1-8.

Maslow, A. H. (1943). A theory of human motivation. Psychological Review, 50(4), 370-396.

Niedenthal, P. M., Ric, F., \& Krauth, G. S. (2006). Psychology of emotion: Interpersonal, experiential, and cognitive approaches. New York: Psychology Press.

Sakti, H., \& Kusuma, G. T. B. (2006). Antara dua sisi: Sebuah kajian psikologi tentang bahaya free sex dan video porno. Jakarta: Sahabat Setia.

Santrock, J. W. (2012). Life-span development; Perkembangan masa hidup (Ed. Benedictine Widyasinta). Jakarta: Gelora Aksara Pratama.

Sarwono, S. W. (2005). Psikologi remaja. Jakarta: Raja Grafindo Persada.

Seniati, L. (2009). Psikologi eksperimen. Jakarta: Indeks.

Shaver, P. R., Morgan, H. J., \& Wu, S. (1996). Is love a "basic" emotion?. Personal Relationships, 3(1), 81-96.

Stanhope, M., \& Lancester, J. (2004). Community \& public health nursing (Six Edition), Missouri: Mosby Elsivier.

Subekhi, A. (2016). Parah, akibat seks bebas 47 siswi di Ponorogo hamil. Retrivied August 15, 2016, from https://daerah.sindonews.com/read/1129869/23/parah-akibat-seks-bebas47-siswi-di-ponorogo-hamil-1470728031.

Potter, P. A., \& Perry, A. G. (2009). Fundamentals of nursing (Seventh edition). Missouri: Mosby Elsivier.

Rani, D. A. M., \& Subekti, E. M. A. (2013). Hubungan antara gaya kelekatan menghindar dengan strategi regulasi emosi expressive suppression pada remaja perokok. Jurnal Psikologi Klinis dan Kesehatan Mental, 2(2), 62-68.

Soekanto, S. (1990). Sosiologi keluarga tentang ikhwal keluarga, remaja dan anak. Jakarta: Rineka Cipta.

Stanhope, M., \& Lancaster, J. (2004). Community \& public health nursing (pp. 612-613). St. Louis: Mosby. 
Strongman, K. T. (2003). The psychology of emotion: From everyday life to theory (Fifth edition). New Jersey: John Wiley \& Sons.

Wibowo, A. (1994). Unsur dasar pelayanan kebidanan pada rujukan tingkat pertama. Jakarta: Binarupsa Aksara.

Widhiana, H. (2013). Survei PKBI: 29 persen siswa SMA setuju seks pranikah. Retrivied November 6, 2013, from http://jateng.tribunnews.com/2013/11/06/survei-pkbi-29persen-siswa-sma-setuju-seks-pranikah 